\title{
Brahe vs. Ursus: Videnskabelig uredelighed i renæssancen
}

I efteräret 1584 havde Tycho Brahe besøg på af sin slagtning Erik Lange - og han kom ikke alene: Med i folget var en ung, selvlert matematiker, Nicolaus Ursus, som under besoget på Hven blev taget $i$ at snuse lige lovlig meget $i$ Tychos papirer.

Det var netop på den tid, Tycho arbejdede på sit verdenssystem, som han udgav $i$ 1588 - samme àr, som bemeldte Ursus også udgav et verdenssystem, som til forveksling lignede Tychos. Tycho var overbevist om, at Ursus havde stjälet hans system og ville have ham retsforfulgt for det intellektuelle tyveri. Men var Ursus overhovedet skyldig?

\section{affhv. bibliotekskonsulent Torsten Schlichtkrull}

$\mathrm{I}$ september 1584 havde Tycho Brahe besøg på Hven. Det havde han tit, for Tycho var berømt i hele Europa, og der var mange, som var interesserede $i$ at se den forskningsinstitution, han havde skabt på Hven. Denne gang var det adelsmanden Erik Lange (d. 1613). Både Erik Lange og Tycho dyrkede kemien ivrigt, og Erik Lange troede i modsætning til Tycho på, at man kunne lave guld af uædle metaller. Erik Lange levede fra 1590 sammen med Tychos lærde søster, Sophie (1555/59-1643), som var enke; de levede i udlændighed og fattigdom, fordi Erik Lange formøblede gods og formue på sine forgæves forsøg på at lave guld men det er en anden historie. I Langes følge var den bondefødte matematiker, Nicolaus Reimarus Ursus (1551-1600). ${ }^{1}$ Ursus er en latinisering af hans fødenavn, Bär. Han var fra Ditmarsken, og han var selvlært. Undervejs vogtede han svin, men på et tidspunkt blev han protegé af den holstenske hertug, Heinrich Rantzau (1526-98). Mens han var hos Rantzau, fik han udgivet to bøger, Grammatica Ranzoviana i 1580 og Geodasia Ranzoviana, 1583.
Besøget på Hven forløb ikke uden kontroverser. De forskellige kilder er ikke helt enige om forløbet, men Ursus synes ikke at være blevet behandlet særlig godt. Han blev drillet, han var opfarende, og han lod sig provokere til diskussioner. En af dem gav anledning til at Tycho udbrød, at "De tyske karle er alle sammen halvgale," en bemærkning Ursus ikke glemte. Ursus snusede også rundt på en mistænkelig måde, så Tycho fik arrangeret, at Ursus blev ransaget, mens han sov, og i hans bukser fandt man "hele håndfulde af skitser og skrifter," som blev fjernet. ${ }^{3}$ Da han om morgenen opdagede, at der manglede papirer i hans bukser, blev han meget oprevet: "Som en rablende galning løb han omkring klynkende, grædende og skrigende, så han knap kunne beroliges." Han fik tilbageleveret de af papirerne, som tilhørte ham selv, og som ikke angik Tycho. Ursus og Erik Lange skiltes kort efter.

Alt dette fandt sted, mens Tycho arbejdede med sit verdenssystem. Sagen var den, at man siden antikken havde antaget et system, hvor Jorden var i midten, og de syv planeter ('vandrestjerner'), kredsede 


\section{GRA PH. PETRIAP. \\ Fo.3. \\ Schema præmiffx diuifionis.}

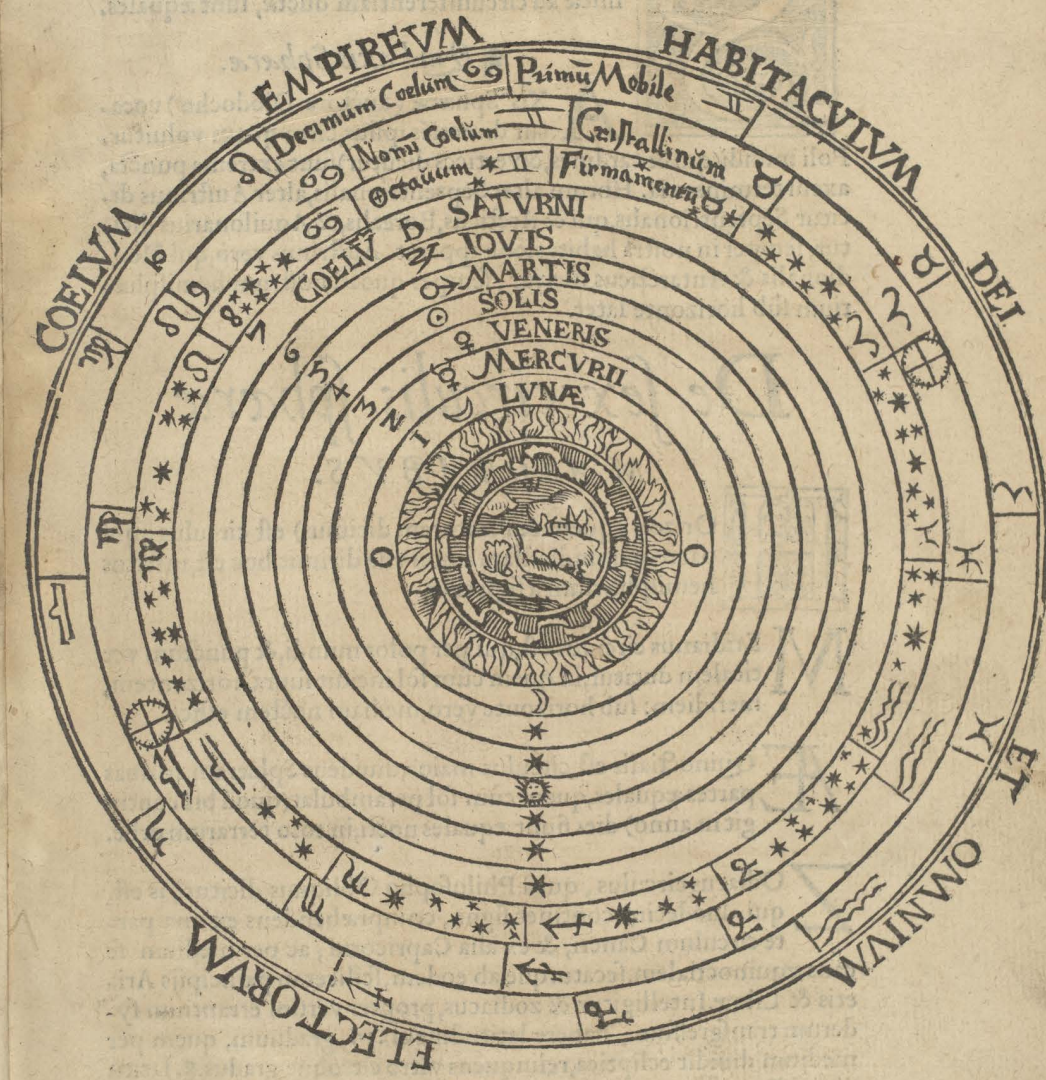

DE CIRCVLIS SPHARA. $C A P$. III.

B

Ill. 1: Det klassiske geocentriske system med den hvilende Jordklode i midten. Rundt om Jorden bevager de syv planeter sig i hver sin krystalsfere, og yderst findes Guds bolig (Habitaculum Dei) og Himmeriget. (Petrus Apianus: Cosmographia Petri Apiani / per Gemmam Frisium apud Louanienses Medicum et Mathematicum insignem, iam demum ab omnibus vindicata mendis, ac nonnullis quoque locis aucta ; additis eiusdem argumenti libellis ipsius Gemmæ Frisij, Antuerpie, 1550). 
om Jorden i jævne cirkelbevægelser. De syv planeter var i rækkefølge fra Jorden: Månen, Merkur, Venus, Solen, Mars, Jupiter og Saturn. Cirklen er den perfekte kreds, og hastigheden var jævn, dvs. den samme hele tiden. Dette geocentriske system passede ikke særlig godt til observationerne, og man havde derfor indført nogle hjælpecirkler, epicykler, som sad fast på hovedcirklen. På den måde kunne man tilnærmelsesvis få systemet til at passe med observationerne. I 1543 udkom Kopernikus' berømte bog, hvor Solen blev gjort til verdens centrum og Jorden gjort til en planet med Månen kredsende om sig som satellit. Det var kontroversielt, og bl.a. Tycho forsøgte at udfinde et system, som kunne bevare Jorden i midten. Han havde arbejdet med det siden $1574,{ }^{4}$ mens han forelæste på Københavns Universitet. Det lykkedes, og systemet blev præsenteret i en bog, som primært handlede om kometen i 1577: De mundi aetherei, 1588. Heri viste han, at kometen fra 1577 krydser de krystalsfærer, som i det klassiske billede holder fast på planeterne. Altså var krystalsfærerne ikke reelle. I Tychos system befinder Jorden sig i midten, og herom kredser Solen med de fem planeter. Månen kredser om Jorden. For at få Marsbanen til at passe med observationerne, lod Tycho Solen og Mars' baner skære hinanden, hvad de ikke havde kunnet, hvis der havde været krystalsfærer.

Tycho havde tidens videnskab på sin side. ${ }^{5}$ I 1651 udgav jesuitten Giovanni Battista Riccioli en bog, Almagestum novum, hvor han ud fra hele tidens videnskab vurderede det geocentriske system mod det tychoniske system. Et af de vigtigste argumenter imod Kopernikus' system var, at man ikke kunne se, at stjernerne skiftede position efterhånden som Jorden gennemløb sin årlige bane omkring Solen, et fænomen, som kaldes parallakse. Det kunne forklares ved, at stjernerne var umådelig langt væk, men så skulle de også være ubegribeligt store. I moderne teleskoper ses stjernerne som et lysende punkt uden udstrækning, men $i$ en periode, hvor teleskoperne ikke var specielt udviklede, kunne man stadig - som Tycho kunne uden brug af det teleskop, som først blev opfundet nogle år efter hans død - måle, at stjernerne har en udstrækning, og man kunne derfor direkte beregne, hvor store stjernerne måtte være, hvis de var så og så langt væk. I dag bruger man betegnelsen magnitude for en stjernes lysstyrke, men som man også kan se af ordet, angav det oprindeligt ikke lysstyrke, men størrelse. Beholdt man Jorden i midten, eksisterede det problem ikke. Kopernikus' og Tychos systemer er, bortset fra at der 'holdes fast' på forskellige himmellegemer (hhv. Solen og Jorden), kongruente, og man kunne ikke observere sig til, hvilket der var rigtigst. Tidens videnskab accepterede heller ikke, at en så stor og tung ting som Jorden kunne bevæge sig.

I vinteren 1585-86 befandt Ursus sig et sted i Polen, og her udtænkte han efter eget udsagn sit system. Det er ikke bekræftet andetsteds. Ursus' system lignede Tychos meget, men der var vigtige forskelle: Jorden roterede om sig selv en gang i døgnet, det gør den ikke hos Tycho, og Solens bane ligger helt inden for Mars,' hvor de to baner skærer hinanden hos Tycho. Endelig tillader Ursus i modsætning til Tycho, at der er forskellige afstande til stjernerne. ${ }^{6}$ I foråret 1586 kom Ursus til Kassel, hvor han viste den astronomisk kyndige landgreve, Wilhelm 4. af HessenKassel sit system. Landgreven kunne godt 


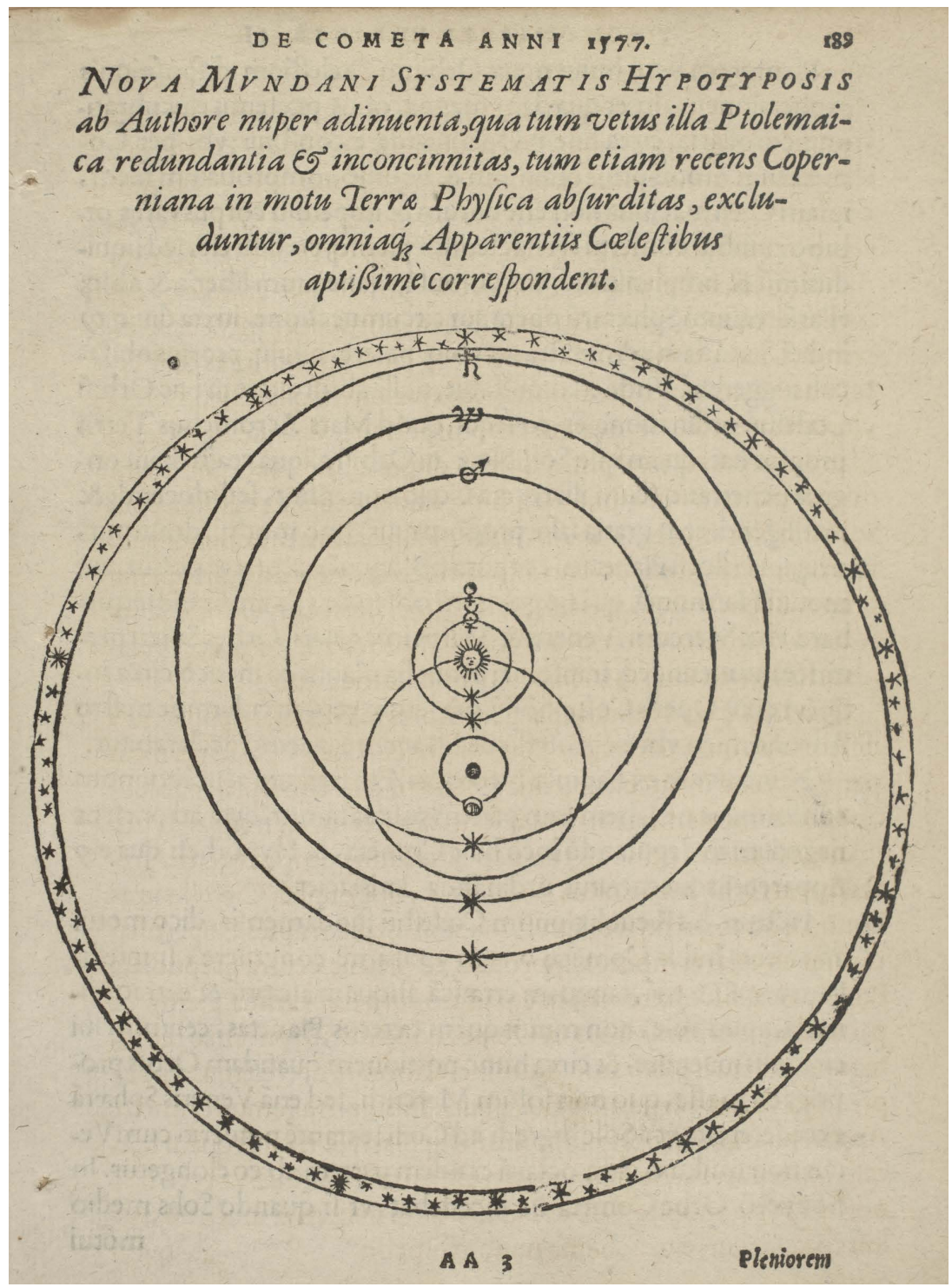

Ill. 2: Tycho Brahes system med Jorden hvilende i midten. Månen kredser om Jorden og det samme gør Solen med de da fem kendte planeter (Merkur, Venus, Mars, Jupiter og Saturn) kredsende om sig. Solens og Mars' baner skerer hinanden. Yderst fiksstjernesferen. (Tycho Brahe: De mundi aetherei recentioribus phaenomenis liber secundus qvi est de illustri stella caudata ab elapso fere triente Nouembris anni 1577, usqve in finem Januarij sequentis conspecta, Uraniburgi, [1588]). 


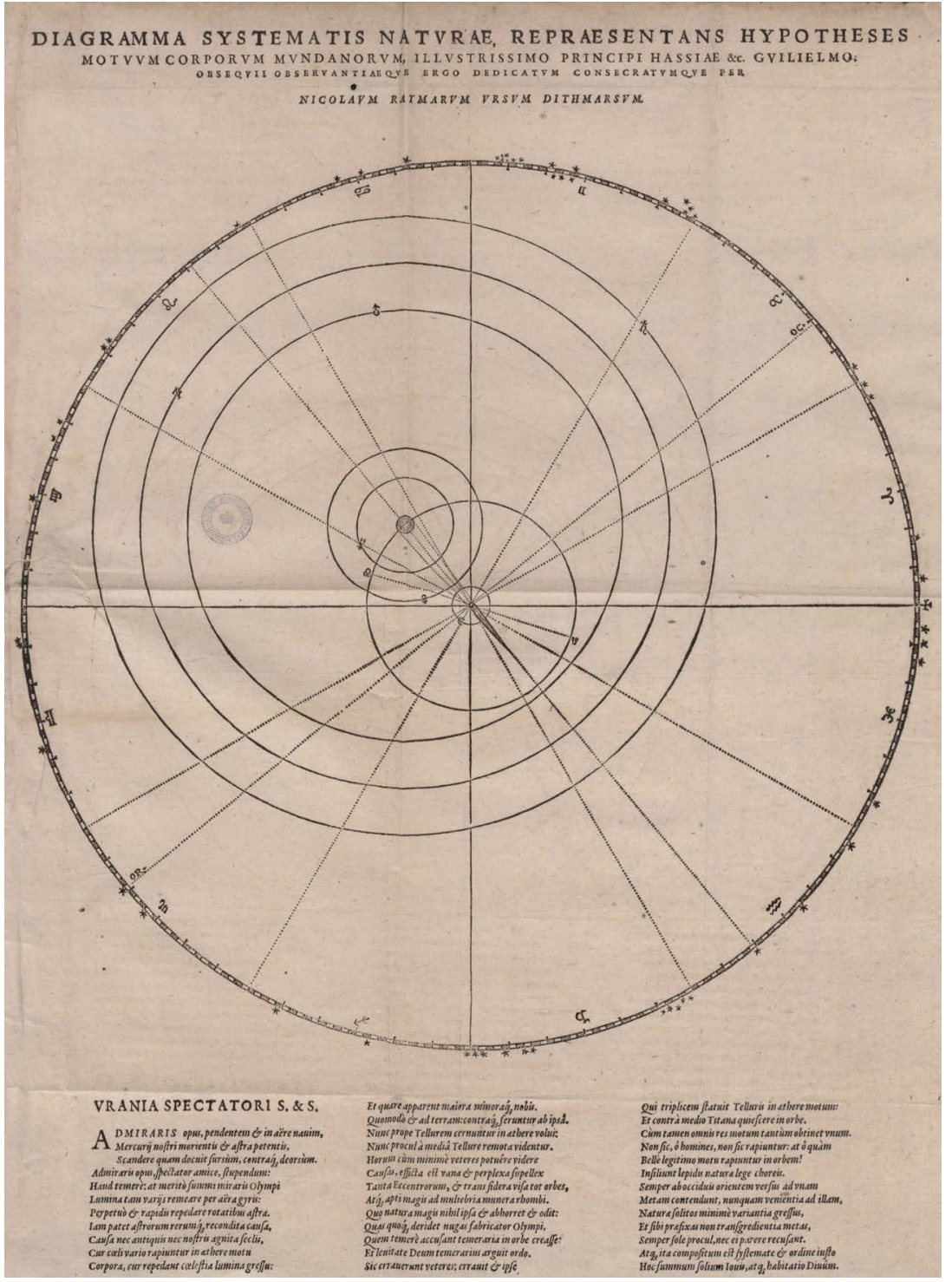

Ill. 3: Ursus' system med Jorden i midten. Månen kredser om Jorden og det samme gor Solen med de fem planeter kredsende om sig. Jorden roterer om sig selv en gang $i$ døgnet, Solens og Mars' baner skarer ikke hinanden, og Ursus har ingen fiksstjernesfere. Stjernerne kan altså have forskellige afstande fra Jorden. (Nicolaus Raimarus Ursus: Fundamentum astronomicum: id est nova doctrina sinuum et triangulorum, Argentorati, 1588).

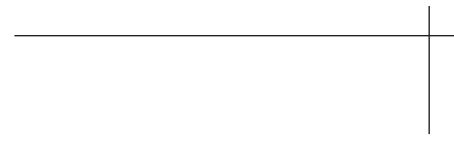


lide systemet og fik sin urmager til at lave en model af det. Ursus forlod hurtigt Kassel, da han ikke kom godt ud af det med landgrevens astronom, Christopher Rothmann (1550-ca. 1608). Ursus bagtalte Tycho. ${ }^{7}$ Senest i $1586 \mathrm{blev}$ der etableret et samarbejde mellem Uraniborg og Kassel, ${ }^{8}$ og Tycho og Rothmann stod i livlig korrespondance indbyrdes.

Tycho arbejdede videre med sit system uden at vide, at Ursus havde været i Kassel og præsenteret sit eget system. Rothmann havde ikke nævnt det i sine breve. Tychos bog, der er blevet beskrevet som prototypen på den videnskabelige monografi, ${ }^{9}$ blev færdig omkring årsskiftet 1587/88. ${ }^{10}$ Først da Tycho i sommeren 1588 sendte et eksemplar af sin bog til Kassel, blev han af Rothmann gjort opmærksom på Ursus' arbejde, og - hvad værre var - at Ursus havde udgivet en bog om sit system. I bogen tilegner Ursus de 21 forskellige tavler til fremtrædende matematikere og/eller astronomer, som måske kunne hjælpe Ursus. Verdenssystemet havde Ursus tilegnet landgreven. Kun Tycho manglede, hvilket Tycho kunne se som en indirekte fornærmelse. ${ }^{11} \mathrm{I}$ bogen publicerer Ursus også en metode til trigonometriske beregninger, prosthaphairese, som han havde lært af den polske matematiker og astronom, Paul Wittich (ca. 1546-1586), men Wittich bliver ikke krediteret. ${ }^{12}$ Wittich havde besøgt Hven i 1580, og her havde han og Tycho sammen videreudviklet prosthapbairese. ${ }^{13}$ Wittich havde i 1578 tegnet, men ikke publiceret, et geoheliocentrisk system noget anderledes end det, Tycho fandt frem til. Wittich viste det til Tycho i $1580 .{ }^{14}$ Wittich døde i 1586 uden at have efterladt sig noget på tryk. Dette åbnede selvsagt muligheder for at tilegne sig Wittichs resultater uden at kreditere ham - og uden risiko for, at Wittich skulle gøre indsigelser.

Tycho var overbevist om, at Ursus havde stjålet hans system. I 1584, hvor Ursus var på Hven, havde Tycho faktisk haft en tegning, hvor Marsbanen ikke skar Solens bane, og det var den, Ursus måtte have tilegnet sig. Tycho ovevejede, hvordan han kunne forfølge Ursus for det mistænkte tyveri, men da det kom til stykket, skete det ikke. ${ }^{15}$ Til gengæld fik Ursus et par ord med på vejen, da Tycho i 1596 udgav dele af sin astronomiske korrespondance, især den med landgreven af Kassel og Rothmann. Ursus bliver flere steder direkte og indirekte anklaget for at have stjålet Tychos system, og hvor han nævnes ved navn, bliver han ikke omtalt i rosende vendinger, i et af brevene - fra Rothmann til Tycho - hedder det:

"Jeg ville gerne skrive mere, især om den der beskidte slyngel Nicolaus Raymarus Ursus fra Ditmarsken, som sidste vinter vistnok arbejdede som typograf hos Din Excellence, nemlig om hvordan han blev ved med at rakke ned på dig og hvordan jeg tog dig i forsvar, hvis ikke manglende tid forhindrede mig i at gøre det." 16

Dette sted er i øvrigt et eksempel på en mindre pæn side af Tycho. Han har redigeret i brevet og sat udtrykket "beskidt slyngel" ind, hvad der passer dårligt med, at Tycho i forbindelse med planerne om at udgive korrespondancen skrev til landgrevens søn, at han "ikke har sat noget af sit eget ind (hvad der ville være en forbrydelse)." ${ }^{17}$ Gennem hele forløbet svinede de to kombattanter hinanden grundigt til, men det er ikke emne for denne artikel.

Efter Christian 4.s tronbestigelse blev tiderne vanskeligere for Tycho, som ikke var uden skyld i den udvikling sagerne tog. Det kan man læse om i enhver Tycho- 
biografi. Slutresultatet var, at Tycho i 1597 forlod Danmark og tog midlertidigt ophold på en af Henrik Rantzaus herregårde i Holsten, Wandsburg. Hertil medbragte han sin familie og sine instrumenter, trykkeri mv., og her fik han i 1598 trykt et af sine hovedværker, Astronomice instaurate mechanica. Bogen blev sendt til fyrster rundt i Europa og er blevet beskrevet som en uopfordret stillingsansøgning: "Europas førende astronom søgte en ny arbejdsgiver." ${ }^{18}$ Tycho arbejdede målrettet på at blive astronom for kejser Rudolf 2 . i Prag. Her var Ursus imidlertid blevet kejserlig matematiker i $1591 .^{19}$

I Wandsburg fik Tycho tilsendt et eksemplar af en ny bog af Ursus, som havde den uskyldige titel De astronomicis hypothesibus, 1597. Indholdet var ikke slet så uskyldigt som titlen. Det var en gennemgang af forskellige teorier, og bogen indeholdt skarpe - og ubeherskede - angreb på Tycho og i anden række på Rothmann. ${ }^{20}$ Eksempler: Der blev sat spørgsmålstegn ved Tychos matematiske evner, det var snarere Tycho, som havde stjålet systemet gennem et forræderi ved den "[Judas] Iskariot" Rothmann, og Tychos system var i øvrigt foregrebet i antikken og udførligt beskrevet hos Kopernikus. Tycho skulle være flygtet fra Danmark på grund af en eller anden misgerning. Der blev naturligvis gjort grin med Tychos næse, og hans familie undgik heller ikke beskydning, for det blev mere end antydet, at hans borgerligt fødte kone, som han ikke var kirkeligt viet til (men efter datidens danske retstilstand blev man anset som ægtefæller, hvis man havde levet sammen i tre år) og hans datter stod til rådighed for alle mændene på Hven. I bogen aftrykte Ursus et brev fra Tycho til Rothmann. Ud for Tychos beskyldning mod Ursus om at være tyv skrev Ursus i en note: "Sit furtum, sed Philosophium: disce in posterum rem tuā custodire" ("Lad det være tyveri, men et filosofisk, og lad det lære dig at passe bedre på dine ting"). Noten er af nogle blevet beskrevet som en regulær tilstålse og af andre som en retorisk bemærkning, typisk for tiden. ${ }^{21}$ Med hensyn til Paul Wittich og prosthaphairese anførte Ursus sin kilde; det havde han ikke gjort i $1588 .{ }^{22}$

I august 1596 havde Ursus søgt om og fået kejserlige privilegier til at udgive et svar på Tychos anklager. Da bogen var færdig, var det dog utænkeligt, at den kunne blive udgivet med disse privilegier, og bogen blev da også trykt "uden ethvert privilegium" og uden angivelse af trykkernavn; begge dele var usædvanligt. Omtrent samtidig hermed var Ursus' stjerne ved hoffet for nedadgående. Man havde opdaget, at et af Ursus' horoskoper ikke var andet end en afskrift fra andres værker. ${ }^{23} \mathrm{Da}$ kejseren selv udspurgte ham nærmere, kunne Ursus ikke forklare sig ordentligt.

Tycho måtte naturligvis svare på Ursus' angreb, og som led heri fik han i oktober 1598 udarbejdet en erklæring fra Erik Lange om Ursus' opførsel på Hven. Det skete som Tycho forlangte. ${ }^{24}$ Tycho fik også erklæringer fra Erik Langes sekretær, Michael Walter, som havde været med på Hven, og Christen Hansen fra Ribe, ${ }^{25}$ som havde været på Hven fra april 1586 og fire år frem. Christen Hansen ankom altså ca. 11/2 år efter, at Ursus havde været der, så det han kunne bevidne var, hvad han havde hørt, ikke hvad han havde oplevet. Walter beskriver ransagningen, Hansen nævner den ikke.

Tycho fik positive meldinger fra Prag, og han forlod Wandsburg for at 
tage til Prag. Det var ikke helt enkelt, og undervejs gjorde han ophold i Magdeburg og Wittenberg. Da han endelig fik besked om, at kejseren gerne ville møde ham, var der pest i Prag, og det forsinkede sagen yderligere. Ursus var ikke uvidende om, hvad der foregik, og inden Tycho nåede frem til Prag, forlod han byen, men han kom tilbage, og her blev han alvorligt syg. ${ }^{26}$ Tycho brød sig ikke om udsigten til, at Ursus skulle undslippe en rettergang ved at $\mathrm{d} ø .^{27}$ Tycho indhentede en erklæring fra Prags ærkebiskop, ${ }^{28}$ som var den officielle censor for byen. Svaret lød, at biskoppen ville opspore trykkeren, udstille ham og beslaglægge de eksemplarer, som måtte være hos trykkeren. Hvad Ursus angik, hørte han ikke under kirkens jurisdiktion, men under den verdslige. Kejseren var imidlertid stadig på flugt fra pesten, så Tycho måtte vente. Tycho lod da to advokater og en offentlig notar opsøge Ursus på hans dødsleje for at få ham til at tilbagekalde beskyldningerne, hvilket han nægtede. På den baggrund opnåede Tycho kejserens tilladelse til en retssag, der dog aldrig blev til noget, fordi Ursus døde. ${ }^{29}$ Restoplaget af $D e$ astronomicucus hypothesibus blev fordømt, beslaglagt og brændt. Enken fik dog erstatning i form af 300 floriner. ${ }^{30}$ Bogen er meget sjælden. En søgning i WorldCat (worldcat.org) åbenbarer kun omkring 20 eksemplarer, hvoraf tre befinder sig i Det Kongelige Bibliotek. I det ene eksemplar, det som stammer fra Universitetsbiblioteket, er der små mærker i margenen, som tydeligvis er sat i forbindelse med striden mellem Tycho og Ursus. Det antages, at der er tale om det eksemplar, Tycho lånte til Holger Rosenkrantz, men som ikke blev tilba- geleveret. ${ }^{31}$ Desværre er der, ud over en håndskreven note, Donum autor, ingen angivelse af proveniens i eksemplaret, og en undersøgelse af Universitetsbibliotekets gamle kataloger i Det Kongelige Bibliotek og i Rigsarkivet giver ikke yderligere oplysninger.

Så vidt forløbet, men som vi har set, ligger der ikke noget håndfast bevis for, at Ursus stjal Tychos system. Vel er det dokumenteret, at Ursus ved at udgive andres arbejde for sit eget og ved at skrive af, selv skaffede sig et dårligt ry, men med hensyn til verdenssystemet er der (med et fortærsket udtryk) ingen rygende pistol. Til gengæld er der forskel på beskrivelsen af forløbet i den danske litteratur og i den udenlandske. I den danske litteratur fremstilles Ursus entydigt som en skurk, og hans matematiske kunnen gøres til tider mindre end den faktisk var. Eksempler:

F.R. Friis: "Med ham [Erik Lange] fulgte iøvrigt en østerrigsk Baron, og tillige en Person ved Navn Reimer Bär fra Ditmarsken (Raimarus Ursus Ditmarsicus) med hvis Besøg Tyge Brahe dog var mindre tilfreds, da han paa en temmelig ubeskeden Maade benyttede Lejligheden til at see Adskilligt, som han senere paastod, at han selv havde opfundet. ... Han var vistnok Student og ikke aldeles blottet for Kundskaber." ${ }^{2}$

Godfred Hartmann: "Men hvad hjælper dygtighed og flid, hvis karakteren er anløben. ... Men eet stod Ursus klart: Tyges spottende ord og hans efterhånden åbenlyse foragt for ditmarskeren skulle hævnes en dag.

Og Ursus glemte ikke, hvad han havde lovet sig selv, da han nok lidt køligt tog afsked med Tyge."33 


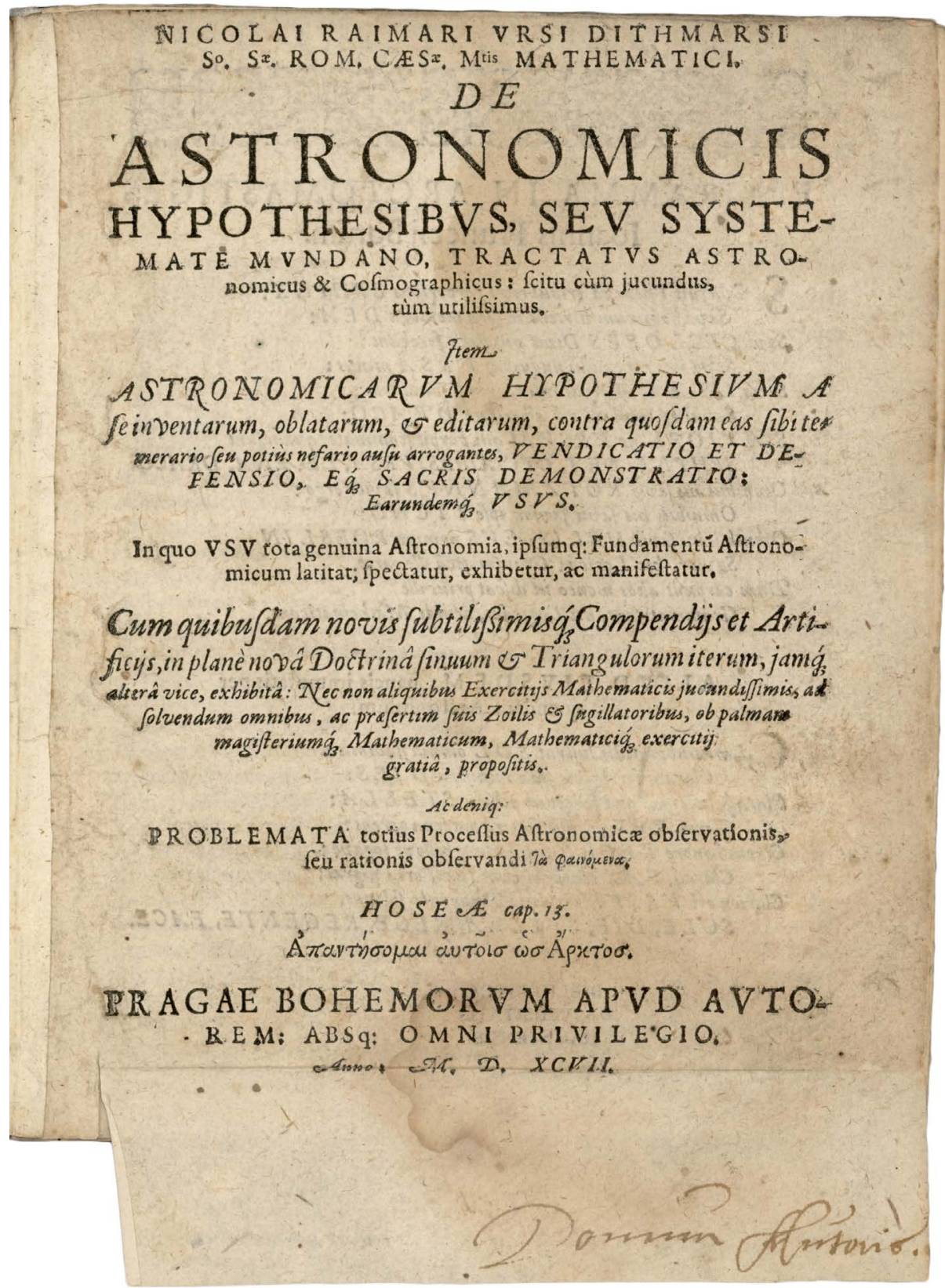

Ill. 4: Titelbladet til Ursus' famose bog hvor han bagtalte Tycho på det groveste. (Nicolaus Raimarus Ursus: De astronomicis hypothesibus, seu systemate mundano tractatus astronomicus et cosmographicus : scitu cum jucundus, tum utilissimus, Pragae, 1597).

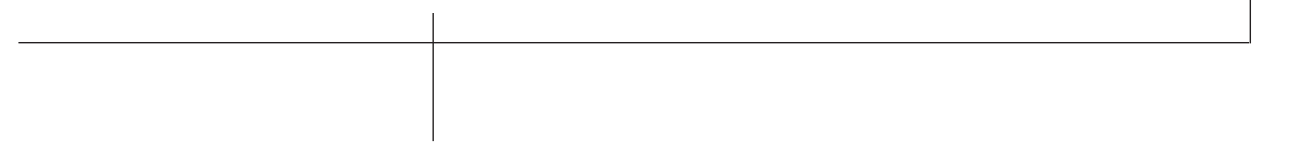


Torkil Morsing: "Han [Ursus] var af fattig familie, men var så gået i gang med at studere matematik." ${ }^{34}$

Alex Wittendorff: "... fire år senere publicerede han [Ursus] noget, der ikke var færdigt, et løst udkast, som han ikke har kunnet gennemskue."35

Eneste dansker, som er klar i mælet om, at Ursus måske ikke er skyldig i denne sag, er J.L.E. Dreyer, der virkede som astronom i Storbritannien: "It must, however, be said that this accusation of plagiarism is founded on very slight evidence, and the verdict of posterity can only be "not proved." In his writings Reymers has shown himself an able mathematician, and there is no reason whatever why he should not independently have arrived at a conclusion similar to the idea which Tycho conceived on the planetary motions." ${ }^{36}$

Den nyeste større monografi på dansk om Tycho Brahe er John R. Christiansons Tycho Brahe. Renessancen på Hven, 2008. Bogen er oversat, Christianson er amerikaner og er ikke i tvivl om, at Ursus stjal systemet, men han er betydeligt mere afdæmpet i sit ordvalg end de danske forfattere.

De trykte danske kilder er heller ikke enige om, hvad der egentlig foregik på Hven i september 1584. Ransagningen har formentlig fundet sted. I et brev til Rantzau fra december 1588 skrev Tycho, at da han havde fået færten af Ursus' gøren og laden, fik han nogen til at skaffe en stor del af det stjålne tilbage. ${ }^{37}$

F.R. Friis: "Men Tyge Brahe meente, at Ursus snarere havde fundet det paa
Uraniborg, dog ikke ved eget Studium, men ved at betragte en Tegning, som han der forefandt og som han afcopierede som den var, uden at bemærke at den havde en væsentlig Feil, hvorfor den var bleven kasseret, saa at heraf fremgik, at han ikke engang havde forstaaet Sagen." ${ }^{38}$

Godfred Hartmann: "Hverken Tyge eller Lange anede uråd. I hvert fald ikke i begyndelsen. Begge behandlede de ham godt, selv om der var et eller andet, der bød Tyge imod. Men han kunne ikke sige, hvad det var.

Tyge kunne bruge ham, og han lod ham læse korrektur på nogle af de skrifter, han havde i arbejde. Men Ursus læste mere end korrektur - Ursus skrev af, hvad han mente han senere kunne bruge. [...]

En dag stod han her med en tegning af Tyges udkast til hans verdenssystem $i$ hånden. Lynsnart fattede han sin plan. Det kunne han bruge. Han vendte tilbage til det, når Tyge var nede i Stjerneborgs kælder - og uden at nogen bemærkede det, kopierede han det." ${ }^{39}$

Torkil Morsing: "Besøget på Hven fandt sted på det tidspunkt, hvor Tycho arbejdede med sit nye verdensbillede, og det må have interesseret Ursus. For mens Tycho morede sig med sine gode venner, gik Ursus på jagt i Tychos bibliotek. Han gennemrodede papirer, undersøgte instrumenter, tog notater og tegnede af efter Tychos tegninger. En af Tychos medarbejdere opdagede, hvad der foregik, og smed ham ud af biblioteket." ${ }^{40}$

Alex Wittendorff: "Det var på den tid, Tyge arbejdede med udformningen af sit verdenssystem, og en dag greb han Ursus $i$ at snuse rundt $\mathrm{i}$ biblioteket i nogle af $\mathrm{Ty}$ - 
ges helt personlige notater. Så blev Ursus smidt ud ..."¹

\section{Plagiat eller ej?}

Nedenstående oversigt er meget kortfattet og medtager slet ikke alt, som taler til gunst eller ugunst for de to parter. En komplet oversigt ville ligge uden for denne artikels rammer. Der er dog næppe tvivl om, hvordan retssagen ville være endt, hvis den var blevet gennemført. En adelsmand stod automatisk stærkt over for en bondefødt.

Det overlades til den ærede læser at fælde dom i denne sag, men man skal huske, at det vil være historisk ukorrekt at lægge nutidens normer ned over, hvad der skete i renæssancen.

\begin{tabular}{|c|c|}
\hline Tycho Brahe & Ursus \\
\hline Inspiration fra Paul Wittich? & Inspiration fra Paul Wittich? \\
\hline $\begin{array}{l}\text { Tycho Brahe er overbevist om, at Ursus } \\
\text { har stjąlet hans system. }\end{array}$ & $\begin{array}{l}\text { Ursus var en begavet matematiker, som } \\
\text { formentlig kunne have konstrueret sit } \\
\text { system på egen hånd. }\end{array}$ \\
\hline $\begin{array}{l}\text { Den beedigede erklæring fra Erik Lange } \\
\text { om Ursus' adfærd på Hven i } 1584 \text { er } \\
\text { optaget } 14 \text { år efter begivenhederne. } \\
\text { Lange var, da han underskrev erklærin- } \\
\text { gen, svoger til Tycho og i øvrigt dybt } \\
\text { forgældet. } \\
\text { Et andet vidneudsagn, fra Erik } \\
\text { Langes sekretær, Michael Walter, er } \\
\text { som erklæringen fra Erik Lange optaget } \\
\text { mange år efter at begivenhederne fandt } \\
\text { sted. } \\
\text { Et tredje vidneudsagn, fra Christen } \\
\text { Hansen fra Ribe baserer sig på, hvad han } \\
\text { hørte, da han kom til Hven noget efter } \\
\text { at Ursus var taget derfra. Det var altså } \\
\text { ikke selvoplevet. }\end{array}$ & $\begin{array}{l}\text { Ursus tog papirer på Hven i } 1584 \text {, } \\
\text { men Tychos system var ikke blandt de } \\
\text { fundne papirer. } \\
\text { Der var ingen "rygende pistol." }\end{array}$ \\
\hline \multirow[t]{2}{*}{$\begin{array}{l}\text { Det er dokumenteret, at Tycho redige- } \\
\text { rede nogle af sine breve til ugunst for } \\
\text { Ursus. }\end{array}$} & $\begin{array}{l}\text { Det er dokumenteret, at Ursus i mere } \\
\text { end ét tilfælde undlod at opgive sine } \\
\text { kilder eller at han direkte skrev af fra } \\
\text { andre. }\end{array}$ \\
\hline & $\begin{array}{l}\text { Ursus tilstår tyveriet i De astronomicis } \\
\text { hypothesibus - eller gør han? Det kan } \\
\text { også være en retorisk bemærkning. }\end{array}$ \\
\hline
\end{tabular}




\section{Noter}

$1<$ de.wikipedia.org/wiki/Nicolaus_Reimers $>$.

2 John Robert Christianson, Tycho Brahe - renassancen på Hven, 2008, s. 102; J.L.E. Dreyer, Tycho Brahe, a Picture of Scientific Life and Work in the Sixteenth Century, 1890, s. 184, <www.kb.dk/e-mat/ dod/130019418287.pdf >.

3 Edward Rosen, Three Imperial Mathematicians, Kepler Trapped between Tycho Brabe and Ursus, 1986, s. 250-253; Christianson 2008, s. 103.

4 Christianson 2008, s. 133 og 406.

5 Christopher M. Graney, Setting aside All Authority, Giovanni Battista Riccioli and the Science against Copernicus in the Age of Galileo, 2015.

6 Nicholas Jardine m.fl., "Tycho v. Ursus: The Build-up to a Trial, Part 1-2," Journal for the History of Astronomy 36, nr. 1-2, 2005, s. 82.

7 Dreyer 1890, s. 184.

8 Christianson 2008, s. 119.

9 Ibid., s. 118 og 136.

10 Ibid., s. 136.

11 Victor E. Thoren, The Lord of Uranienborg, a Biography of Tycho Brahe, 1990, s. 391.

12 Ibid., s. 283.

13 Ibid., s. 237f.; Christianson 2008, s. 405.

14 Christianson 2008, s. 133 f.

15 Thoren 1990, s. 390.

16 Oversættelse: Erik Petersen.

17 Thoren 1990, s. 394.
18 Kristian Peder Moesgaard, "Tyge Brahe," Dansk Biografisk Leksikon, 1984, 1979, $<$ denstoredanske.dk/index.php? sideId $=287516>$.

19 Thoren 1990, s. 390.

20 Jardine m.fl. 2005, s. 83; Thoren 1990, s. $392 \mathrm{f}$.

21 Thoren 1990, s. 393, note 65.

22 Ibid., s. 283.

23 Ibid., s. $391 f$.

24 Christianson 2008, s. 245.

25 Rosen 1986, s. $246 \mathrm{ff}$.

26 Thoren 1990, s. 441; Jardine m.fl. 2005, s. 86.

27 Jardine m.fl. 2005 , s. 86 .

28 Thoren 1990, s. 453.

29 Ibid., s. 454.

30 Jardine m.fl. 2005, s. 94.

31 Ibid., s. 97-106.

32 F.R. Friis, Tyge Brahe, en historisk Fremstilling efter trykte og utrykte Kilder, 1871, s. 138 og 173, <www.kb.dk/e-mat/ $\mathrm{dod} / 130019418252 . \mathrm{pdf}>$.

33 Godfred Hartmann, Urania, om mennesket Tyge Brahe, 1989, s. 135f.

34 Torkil Morsing, Den ukendte Tycho Brahe, 2003, s. 55.

35 Alex Wittendorff, Tyge Brahe, 2006, s. 262.

36 Dreyer 1890, s. 185.

37 Rosen 1986, s. 39.

38 Friis 1871, s. 174.

39 Hartmann 1989, s. 135.

40 Morsing 2003, s. 55f.

41 Wittendorff 2006, s. 262. 